\title{
ASSOCIATION BETWEEN QUALITY OF LIFE AND PERCEIVED STRESS IN PATIENTS WITH VITILIGO: CASE CONTROL STUDY
}

\author{
ASSOCIAÇÃO ENTRE QUALIDADE DE VIDA E ESTRESSE PERCEBIDO EM \\ PORTADORES DE VITILIGO: ESTUDO CASO-CONTROLE
}

\begin{abstract}
Kenia Alves Pereira LACERDA ${ }^{1}$; Luiz Almeida SILVA² ${ }^{2}$ Guilherme Silva MENDONCA ${ }^{3}$; Rafael Alves GUIMARÃES ${ }^{4}$; Lídia Andreu GUILO ${ }^{5}$

1. Federal Institute of Education, Science and Technology of Goias, Câmpus Jataí, GO, Brazil. kenialacerdaalves@gmail.com; 2. Biotechnology academic unit, Federal University of Catalão, Catalão, GO, Brazil; 3. Doctorate in Health Sciences - Federal University of Uberlândia, Nurse at the Hospital de Clínicas, Federal University of Uberlândia, MG, Brazil; 4. Doctorate in the Graduate Program in

Tropical Medicine. Nurse. Goias Federal University, Brazil. Goiânia, GO, Brazil. 5. Goias Federal University, Institute of Biological Sciences, Campus II Laboratory of Cell Biochemistry, Garden Fern. Goiânia, GO, Brazil.
\end{abstract}

\begin{abstract}
To evaluate the association between quality of life (QL), perceived stress in patients with vitiligo and compare the perception of stress with noncarriers. The first study was cross-secctional, and the second case-control with 51 patients in outpatient treatment and 51 users of a blood center, matched by sex and age. Questionnaires used were Dermatology Life Quality Index and Perceived Stress Scale. Results: The mean score of quality of life in patients was $4.7 \pm 5.8$, showing a slight impairment in QL. There was association between QL and black skin color $(\mathrm{p}<0.001)$, involvement of standard exposed vitiligo $(\mathrm{p}<0.001)$ and perceived stress $(p=0.033)$. The perceived stress rated among the groups showed an average of $20.7 \pm 6.0$ and $17.8 \pm 7.0$ for cases and controls, respectively. Vitiligo patients had higher perceived stress compared to the control group $(p=0.022)$. The results showed a high perceived stress in patients with vitiligo, suggesting that the disease increases the level of stress. The overall score of the quality of life was relatively low indicating mild impairment of disease on quality of life.
\end{abstract}

KEYWORDS: Skin. Perceived Stress. Quality of life.

\section{INTRODUCTION}

Vitiligo is an acquired hypomelanosis of skin pigmentation characterized by the development of macromolecules and acromic spots on the skin and mucous membranes, often presenting typical symmetrical distribution and progressive extension (ALIKHAN et al., 2011). It is estimated that the prevalence of vitiligo varies from less $0.4 \%$ to $2.0 \%$ worldwide (SILVERBERG, 2015). Recently, a meta-analysis with 103 studies estimated a combined prevalence of vitiligo of $0.2 \%$ and $1.8 \%$ in population-based investigations and hospital studies respectively (ZHANG et al., 2016).

Although vitiligo does not cause physical disability, it can lead to great psychological impact, significantly impairing the individual's quality life (QL). The impact of clinical symptoms of vitiligo on patients' QL is often underestimated and there are few reports in the literature on this topic, especially in developing countries such as Brazil.

In the last decades, the number of instruments used to assess the quality life has increased and it can be divided in generic or specific. The Dermatology Life Quality Index (DLQI) is a specific instrument for dermatological diseases and in this study it was used to measure the quality of life of patients who have vitiligo (PARSAD et al., 2003; BOTH; ESSINK-BOT; BUSSCHBACH, 2007). It consists of 10 items, which estimate the influence of the disease on symptoms, daily activities, leisure, work, school, personal relationships and treatment. It was translated and validated for the Brazilian version and widely applied in studies in dermatology (MARTINS; ARRUDA; MUGNAINI, 2004).

The stress is a factor related to the manifestation and development of diseases, such as vitiligo, which also contributes to an alteration in the perception of QL. Considering the need to measure the perceived stress and the lack of instruments in the Portuguese language that could supply this need, it has performed the validation of Perceived Stress Scale (PSS-10) for the Brazilian version (REIS; HINO; AÑEZ, 2010). The items were designed to verify how unpredictable, uncontrollable and how much the respondents are evaluating their lives (REIS; HINO; AÑEZ, 2010). The consideration of psychological factors is important for evaluation, treatment and some aspects of the prevention of dermatological problems (HONGBO et al., 2005). 
This study aimed to evaluate the association between quality life, perception of stress in patients with vitiligo and to compare the perception of stress with non - patients.

\section{MATERIAL AND METHODS}

\section{Study Design}

Initially, a case-control study was conducted to verify the association between vitiligo and perceived stress. Next, a cross-sectional design was conducted to analyze factors associated with QL in patients with vitiligo.

\section{Participants}

Initially a survey was conducted in the medical records of a medium size hospital, located in the southwestern region of the state of Goiás (Central-western Brazil) with the intention to carry out the survey of patients with vitiligo who were in outpatient treatment. There were 730 medical records of patients treated in with different types of diseases the period from January 2014 to January 2015.

At the end, there were 90 cases of vitiligo patients. All the patients were invited via telephone to participate in the study, using as exclusion criterion, age under 18 years old. Subsequently, the questionnaires were applied after scheduled appointments with the dermatologist for the patients who were being treated. Patients who were not receiving treatment were scheduled to visit their homes for questionnaires, which occurred within a period of eight months. At the end, 51 participants were interested in participating in the project.

Aiming to make a comparison about the perception of the stress of the carriers with people who did not carry vitiligo, we sought the recruitment of a group of volunteers, who were matched in age and sex.

In the hospital of the study, it has a blood center, where the voluntary controls were also recruited, initially 100 people were invited via telephone. Participants were approached on the scheduled days for donation, achieving the same quantitative case group, 51 participants, and it was used the same exclusion factor as in the case group.

A total of 102 paired people were evaluated in age and sex, with 51 patients diagnosed with vitiligo who constituted the case group and the other 51 patients who did not have vitiligo as the control group. Three questionnaires were applied, after presentation of the project aims, reading and signing of the Term of Free and Informed Consent and clarification of doubts if they were submitted by the volunteer.

The first questionnaire consisted of demographic variables of each participant as age, sex, marital status, schooling and when carrier, how long in years that had vitiligo and if had already undergone treatment, the type of vitiligo, location of vitiligo, pattern of involvement and skin color.

Following, the second questionnaire was used in the likert scale format, DLQI, and the Perceived Stress Scale (PSS-10), both validated for the Brazilian version (REIS; HINO; AÑEZ, 2010).

The DLQI questionnaire consists of ten items, related to specific QL, divided into six domains: symptoms and feelings, daily activities, leisure, work / school, personal relationships. Each item has four alternatives for responses: none, a little, enough, and really a lot, which correspond to the scores of 0 to 3 , respectively (HONGBO et al., 2005).

The total DLQI score was computed from the sum of the indexes assessed and interpreted in: without QL impairment when the scores were between (0-1), light impairment (2-5), moderate impairment (6-10), severe impairment (11-20) and very serious impairment (21-30). Responses with no relevance and unanswered questions were scored with a value of zero. The total score was calculated by summing the scores of all the questions, being able to reach a maximum of 30 and a minimum of zero in this score (HONGBO et al., 2005).

And finally the PSS-10 scale was applied, the questions are about feelings and thoughts during the last 30 days, which was analyzed from the sum of the results of the 10 questions. The total score was obtained by summing the values of the 10 items, and high values mean a high level of stress. The PSS-10 scale was analyzed from the sum of the results of 10 questions and previously inverted questions 4, 5, 7 and 8. To obtain scores, questions 4, 5, 7 and 8 have positive points, being 0 worth 4 points and 4 worth 0 points. They are simple questions composed of 10 items, Likert type, with a variation from 0 (never) to 4 (almost always) (REIN; HINO; AÑEZ, 2010).

\section{Statistical analysis}

The data were analyzed in STATA software, version 14.0. The verification of the normality of the quantitative variables was performed using the Shapiro-Wilk test (RAZALI; WAH, 2011). Quantitative variables were presented with mean, standard deviation (SD), median and interquartile range (IIR). Qualitative variables were expressed as absolute and relative frequency. 
For the internal trustworthiness analysis of the scales used (PSS-10 and DLQI) Cronbach's alpha was applied, with an acceptable internal consistency above 0.7 (TAVAKOL; DENNICK, 2011).

Initially, the groups were compared for sociodemographic characteristics (cases versus controls). Pearson's chi-square test $\left(\mathrm{X}^{2}\right)$ was used to verify differences in proportions between qualitative variables.

To verify the factors associated with QL (dependent variable) in vitiligo patients, a bivariate analysis was performed through the following tests: Spearman correlation coefficient (rs) for quantitative variables and Mann - Whitney U test or Kruskall-Wallis test for qualitative variables. Variables with $\mathrm{p}<0.20$ values were included in a linear regression model with robust variance. The model was adjusted for all covariables (independent variables): age (years), sex (male or female), marital status (separated or married), schooling, vitiligo time (years), skin color, vitiligo type, pattern of involvement, location of vitiligo, prior treatment (yes or no), and perceived stress measured by PSS10.The model was evaluated for the normality of residues by the Shapiro-Wilk test (RAZALI, WAH, 2011), multicollinearity by VIF (DRAPER; SMITH, 1998), homoscedasticity by the White test (1980) and Ramsey RESET test specification (AHMED et al., 2016). Cook's distance was used to check potential outliers.

For comparisons of global perceived stress (PSS-10) and per-component scores, Student's ttests for independent samples were used for the variables with normal distribution or Mann Whitney $U$ test for items with non-normal distribution. To verify the association between vitiligo and perceived stress, a logistic regression with robust variance was performed. The model was adjusted for marital status and schooling, considered in this study as potential confounders. In all tests, a value of $\mathrm{p}<0.05$ was considered statistically significant.

\section{Ethical aspects}

This study was approved by the Research Ethics Committee at the Federal University of Goiás, under approval Opinion Number 38488314.0.0.0000.5083. The study met and respected the guidelines and regulatory standards of resolution 466/12.

\section{RESULTS}

\section{Characterization of the sample}

51 patients with vitiligo participated in the study, who were enrolled in the outpatient records that were part of the case group and 51 individuals from the hemocenter, without diagnosis of vitiligo, who constituted the control group. The case and control groups were similar in relation to the marital status $(p>0.05)$. However, there was a higher proportion of individuals with higher level of education (higher education) in the control group when compared to the case group $(\mathrm{p}=0.035)$ (Table $1)$.

The majorities of individuals with vitiligo had education until high school $(56.9 \%)$ and were married $(56.9 \%)$. The average age was 44.8 years $(\mathrm{SD}+13.4)$. Still, the majority $(68.6 \%)$ had a diagnosis time of vitiligo over 10 years. As for skin color, $35.3 \%, 43.1 \%$ and $21.6 \%$ of the subjects had white, moderate brunette and black skin respectively. Regarding the types of vitiligo and location of the spots, $88.2 \%$ were diagnosed as nonsegmental type. As for the involvement pattern $(47.1 \%)$, they had spots in non-exposed areas and $(52.9 \%)$ had spots in exposed areas. Previous treatment of the dermatoses was identified in 45 volunteers $(88.2 \%)$ and 38 of those mentioned have made treatment using a plant commonly known as "mama-cadela" (Brosimum gaudichaudii) in its many formulations (ointment, teas and tablets) (Table 1).

\section{Perceived stress analysis}

The internal trustworthiness analysis of the PSS-10 has presented Cronbach's alpha of 0.789 for the total sample, 0.832 for the control group and 0.721 for the case group, indicating good internal reliability (TAVAKOL; DENNICK, 2011). The average scores of the PSS-10 were 20.7 points (SD +6.0 ) and 17.8 (SD + 7.0), respectively. It was verified that the case group obtained higher averages of perceived stress when compared to the control group $(\mathrm{p}=0.029)$ (Figure 1).

After adjusting for schooling and marital status in a logistic regression model, there was a positive association between perceived stress in PSS-10 and vitiligo (adjusted odds ratio 1.06, CI 95\%. 1.01-1.13; $\mathrm{p}=0.040)$.

\section{Factors associated with $Q \mathbf{L}$}

The DLQI instrument showed internal trustworthiness of 0.869 . The overall DLQI average between vitiligo patients was 4.7 points $(\mathrm{SD} \pm 5.8$; median: 3.0 ; IIQ: 0.0 to 6.0 ). Regarding the dimensions of DLQI, the domains presented mean scores $(1.3 \pm 2.0$; median: 0.0 ; IIQ: 0.0 to 3.0$)$ to perform daily activities $(1.1 \pm 1.4$, median: 1.0 ; IIQ: 
00 to 2.0 symptoms and feelings $(1.1 \pm 1.6$; median: 0.0; IIQ: 0.0 - to 1.0), leisure, followed by personal relations domains $(0.6 \pm 1.0$, median: 0.0 , IIQ: 0.0 to 1.0$)$, work and school $(0.1 \pm 0.4$, median: 0.0 , IIQ: $0.0-0.0)$ and $(0.2 \pm 0.4$, median: 0.0, IIQ: $0.0-$ 0.0 ) for the treatment domain.

Table 1. Characterization of the sample, according to sociodemographic variables (case group and control group) related to vitiligo (case group), Brazil

\begin{tabular}{|c|c|c|c|}
\hline Variables & Cases $(n=51)$ & Controls $(n=51)$ & $p$ \\
\hline \multicolumn{4}{|l|}{ Marital Status, n (\%) } \\
\hline Single / Divorced / Widowed & $22(43,1)$ & $15(29,4)$ & $0,149^{b}$ \\
\hline Married & $29(56,9)$ & $36(70,6)$ & \\
\hline \multicolumn{4}{|l|}{ Schooling, n (\%) } \\
\hline I degree complete / incomplete & $11(21,6)$ & $6(11,8)$ & $\mathbf{0 , 0 3 5 ^ { b }}$ \\
\hline High School & $18(35,3)$ & $10(19,6)$ & \\
\hline Higher education & $22(43,1)$ & $35(68,6)$ & \\
\hline \multicolumn{4}{|l|}{ Skin Color } \\
\hline White & $18(35,3)$ & NA & \\
\hline Moderate Brunette & $22(43,1)$ & & \\
\hline Black & $11(21,6)$ & & \\
\hline \multicolumn{4}{|l|}{ Time of vitiligo (years), $\mathrm{n}(\%)$} \\
\hline$<10$ & $16(31,4)$ & NA & - \\
\hline$>10$ & $35(68,6)$ & & \\
\hline \multicolumn{4}{|l|}{ Treatment for vitiligo } \\
\hline Not & $6(11,8)$ & NA & \\
\hline Yes & $45(88,2)$ & & \\
\hline \multicolumn{4}{|l|}{ Type of vitiligo } \\
\hline Do not target & $45(88,2)$ & NA & \\
\hline Segment & $6(11,8)$ & & \\
\hline \multicolumn{4}{|l|}{ Location of vitiligo } \\
\hline Located & $45(88,2)$ & NA & \\
\hline Unisegment & $6(11,8)$ & & \\
\hline \multicolumn{4}{|l|}{ Wrapping pattern } \\
\hline Non exposed área & $24(47,1)$ & NA & \\
\hline Exposed Area & $27(52,9)$ & & \\
\hline
\end{tabular}

Variables Cases $(n=51)$ Controls $(n=51) p$

a. Student $t$ test for independent samples; $b$. Pearson's chi-square test; B. NA- not applicable

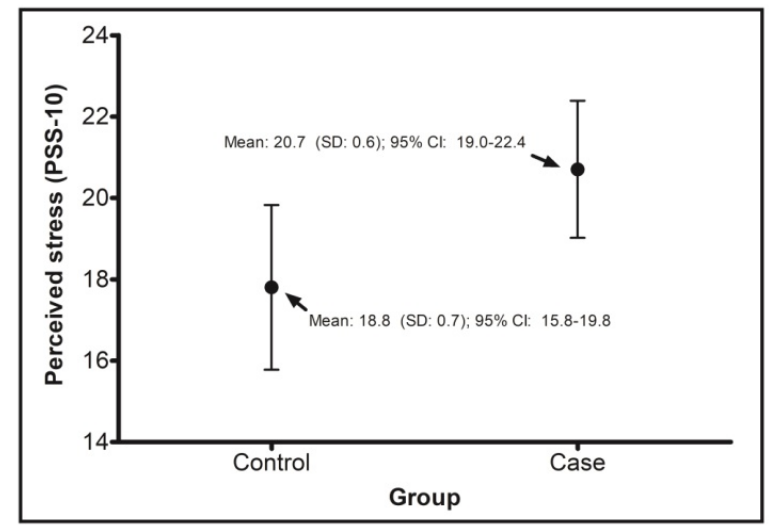

Figure 1. Distribution of the average PSS-10 scores between the case and control groups

Table 2 presents the bivariate analysis of the potential factors associated with QL in patients with vitiligo. In this analysis, there was a statistical difference between skin color and QL $(p=0.002)$. Individuals with exposed wrapping patterns had higher QL scores when compared to non-exposed 
ones ( $\mathrm{p}<0.001)$. Also, a positive correlation was 0.366, $\mathrm{p}=0.016)$ (Figure 2).

observed between perceived stress and QL (rs =

Table 2. Distribution of DLQI scores in patients with vitiligo, according to sociodemographic and clinical conditions.

\begin{tabular}{|c|c|c|c|}
\hline \multirow[t]{2}{*}{ Variables } & \multicolumn{2}{|l|}{ DLQI } & \multirow[t]{2}{*}{$\boldsymbol{P}$} \\
\hline & Média + DP & Mediana (IIQ) & \\
\hline Age (Years) & $-0,103^{b}$ & & $0,463^{b}$ \\
\hline \multicolumn{4}{|l|}{ Sex } \\
\hline Female & $5,1 \pm 6,1$ & $2,0(0,0-9,0)$ & \multirow[t]{2}{*}{$0,779^{\mathrm{c}}$} \\
\hline Male & $3,9 \pm 5,1$ & $3,0(0,0-5,2)$ & \\
\hline \multicolumn{4}{|l|}{ Marital Status } \\
\hline Single / Divorced / Widowed & $4,8 \pm 6,4$ & $4,0(0,0-14,2)$ & \multirow[t]{2}{*}{$0,699^{\mathrm{c}}$} \\
\hline Married & $4,6 \pm 5,4$ & $3,0(0,0-6,0)$ & \\
\hline \multicolumn{4}{|l|}{ Schooling } \\
\hline I degree complete / incomplete & $3,8 \pm 4,3$ & $3,0(0,0-7,0)$ & \multirow[t]{3}{*}{$0,604^{\mathrm{d}}$} \\
\hline High School & $4,1 \pm 5,5$ & $1,5(0,0-6,0)$ & \\
\hline Higher education & $5,6 \pm 6,7$ & $3,0(1,0-7,5)$ & \\
\hline \multicolumn{4}{|l|}{ Skin Color } \\
\hline White & $1,3 \pm 1,6$ & $1,0(0,0-2,3)$ & \multirow[t]{3}{*}{$\mathbf{0 , 0 0 2}{ }^{\mathrm{d}}$} \\
\hline Moderate Brunette & $4,5 \pm 4,4$ & $4,0(0,8-6,0)$ & \\
\hline Black & $10,5 \pm 7,9$ & $11,0(1,0-18,0)$ & \\
\hline \multicolumn{4}{|l|}{ Time of vitiligo (years) } \\
\hline$<10$ & $3,8 \pm 4,7$ & $2,5(0,3-4,7)$ & \multirow[t]{2}{*}{$0,757^{\mathrm{c}}$} \\
\hline$>10$ & $5,1 \pm 6,2$ & $3,0(0,0-6,0)$ & \\
\hline \multicolumn{4}{|l|}{ Treatment for vitiligo } \\
\hline Not & $4,0 \pm 3,9$ & $3,5(0,0-7,8)$ & \multirow[t]{2}{*}{$0,966^{\mathrm{c}}$} \\
\hline Yes & $4,8 \pm 6,0$ & $2,0(0,0-6,0)$ & \\
\hline \multicolumn{4}{|l|}{ Type of vitiligo } \\
\hline Do not target & $4,8 \pm 5,6$ & $3,0(0,5-6,0)$ & \multirow[t]{2}{*}{$0,279^{\mathrm{c}}$} \\
\hline Segment & $4,0 \pm 7,3$ & $0,0(0,0-9,0)$ & \\
\hline \multicolumn{4}{|l|}{ Location of vitiligo } \\
\hline Located & $2,3 \pm 2,4$ & $2,0(0,0-4,5)$ & \multirow[t]{2}{*}{$0,476^{\mathrm{c}}$} \\
\hline Unisegment & $5,0 \pm 6,0$ & $3,0(0,0-6,5)$ & \\
\hline \multicolumn{4}{|l|}{ Wrapping pattern } \\
\hline Non exposed area & $1,1 \pm 1,4$ & $0,0(0,0-2,0)$ & $<0,001^{\mathrm{c}}$ \\
\hline Exposed Area & $7,9 \pm 6,3$ & $6,0(3,0-12,0)$ & \\
\hline PSS-10 & $0,336^{\mathrm{b}}$ & & $0,016^{b}$ \\
\hline
\end{tabular}

b. Spearman correlation coefficient; W. Mann-Whitney U test of independent samples; d. Kruskal-Wallis test of independent samples.

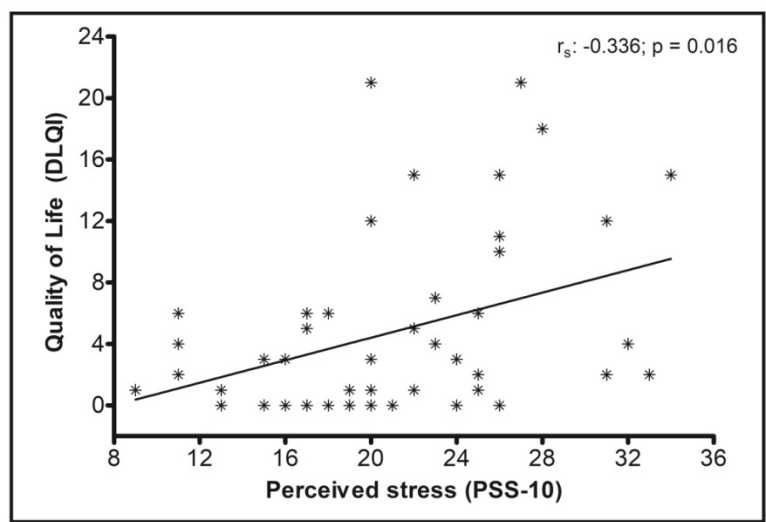

Figure 2. Correlation between Quality of Life and Perceived Stress in vitiligo patients 
The results of the multiple linear regression of factors associated with QL are presented in Table 3. After adjustment for the other covariates, an association between perceived stress and QL was observed $(\beta: 0.22, \mathrm{p}=0.033)$. A positive association between black color and QL $(\beta: 5.64, \mathrm{p}=0.030)$ was observed, as well as the pattern of involvement and QL ( $\beta$ : 5.22, $\mathrm{p}<0.001)$. The final model did not show problems of multicollinearity (mean VIF: 1.60), residue normality (Shapiro-Wilk test: $Z=$ $1.35, \mathrm{p}=0.088$ ) and specification (Ramsey RESET: $\mathrm{p}=0.091)$.

Table 3. Independent factors associated with QOL of patients with vitiligo

\begin{tabular}{|c|c|c|c|c|c|}
\hline Variáveis & $\beta^{\mathbf{a}}$ & IC 95\% ${ }^{b}$ & $\mathbf{E P}^{\mathbf{c}}$ & $\mathbf{t}$ & $P$ \\
\hline Age (Years) & $-0,07$ & $-0,13 ; 0,10$ & 0,06 & $-0,29$ & 0,772 \\
\hline \multicolumn{6}{|l|}{ Sex } \\
\hline Female & Ref. $^{\text {d }}$ & & & & \\
\hline Male & $-1,35$ & $-4,55 ; 1,85$ & 1,58 & $-0,86$ & 0,398 \\
\hline \multicolumn{6}{|l|}{ Marital Status } \\
\hline Single / Divorced / Widowed & Ref. $^{\text {d }}$ & & & & \\
\hline Married & $-0,98$ & $-3,81 ; 1,84$ & 1,39 & $-0,71$ & 0,485 \\
\hline \multicolumn{6}{|l|}{ Schooling } \\
\hline I degree complete / incomplete & Ref. $^{\text {d }}$ & & & & \\
\hline High School & $-0,03$ & $-3,11 ; 3,04$ & 1,51 & $-0,02$ & 0,982 \\
\hline Higher education & 1,98 & $-0,78 ; 4,75$ & 1,15 & 1,45 & 0,154 \\
\hline \multicolumn{6}{|l|}{ Skin Color } \\
\hline White & Ref. $^{\text {d }}$ & & & & \\
\hline Moderate Brunette & 1,62 & $-0,95 ; 3,20$ & 1,27 & 1,28 & 0,210 \\
\hline Black & 5,64 & 0,$58 ; 10,17$ & 2,49 & 2,26 & 0,030 \\
\hline \multicolumn{6}{|l|}{ Time of vitiligo (years) } \\
\hline$<10$ & Ref. $^{d}$ & & & & \\
\hline$>10$ & $-0,30$ & $-3,25 ; 2,63$ & 1,45 & $-0,21$ & 0,833 \\
\hline \multicolumn{6}{|l|}{ Treatment for vitiligo } \\
\hline Not & Ref. $^{d}$ & & & & \\
\hline Yes & $-0,60$ & $-3,60 ; 2,40$ & 1,48 & $-0,40$ & 0,688 \\
\hline \multicolumn{6}{|l|}{ Type of vitiligo } \\
\hline Do not target & Ref. $^{d}$ & & & & \\
\hline Segment & $-0,93$ & $-4,98 ; 3,11$ & 1,99 & $-0,47$ & 0,642 \\
\hline \multicolumn{6}{|l|}{ Location of vitiligo } \\
\hline Located & Ref. $^{d}$ & & & & \\
\hline Unisegment & $-1,67$ & $-3,96 ; 0,62$ & 1,13 & $-1,48$ & 0,148 \\
\hline \multicolumn{6}{|l|}{ Wrapping pattern } \\
\hline Non exposed area & Ref. $^{d}$ & & & & \\
\hline Exposed Area & 5,22 & 2,$49 ; 7,95$ & 1,34 & 3,88 & $<0,001$ \\
\hline Perceived stress (PSS-10) & 0,22 & 0,$02 ; 0,43$ & 0,10 & 2,21 & $\mathbf{0 , 0 3 3}$ \\
\hline
\end{tabular}

a. Regression coefficient; B. 95\% confidence interval; W. Standard error; d. Reference category; R2: 0.594; Model adjusted for age, sex, marital status, schooling, vitiligo time, skin color, type of vitiligo, pattern of involvement, location of vitiligo; previous treatment and perceived stress.

\section{DISCUSSION}

In the central-western region of Brazil, this was the first study to evaluate the factors associated with QL in patients with vitiligo, and compared stress as an emotional factor in people with vitiligo with stress of non-carriers. The results showed an association between QL and black skin color, exposed disease pattern and perceived stress. Also, there was an association between perceived stress and vitiligo.

The mean score in the DLQI of the present study was similar to that found in investigations conducted in patients with vitiligo in the USA (5.9) (SILVERBERG, SILVERBERG, 2013), Italy $(4,3)$ (INGORDO et al., 2012), Singapore (4.4) (CHAN et al., 2013), Belgium (4.9) (CHAN et al., 2013) and Argentina (4.0) (MERLI et al., 2014). This result indicates light impairment in the QL of these 
individuals. On the other hand, some studies have demonstrated higher QL scores in patients with vitiligo, such as those conducted in Germany (7.0) (RADTKE et al., 2009), France $(7,2)$ (KOSTOPOULOU et al. 2009), Iran (8.2) (MASHAYEKHI et al., 2010) and China (8.4) (WANG; WANG; ZHANG, 2011). In addition to methodological differences between studies, the differences in DLQI scores between studies in different geographic locations are due to personal and local risk factors for QL, such as darker skin color, local prejudice, among others.

In the present study, there was an association between black skin color and QL. In general, vitiligo is associated with greater negative social, emotional and psychological implications in black individuals when compared to white color ones (DATSUHI et al., 2008). Besides, lesions caused by the disease are especially more marked and visible in individuals with darker skin (PARSAD et al., 2003). These factors may contribute to decreased QL of subjects with black skin color.

Vitiligo may be located in the body, in exposed or non-exposed areas, however, it may spread and cover large body surfaces (DOLATSHAHI et al., 2008). Some studies have shown that the QL in vitiligo patients is significantly affected by the extent and exposure of the disease on the body surface (SILVERBERG; SILVERBERG, 2013; RADTKE et al., 2009; WANG; WANG; ZHANG, 2011; SHAH; COATES, 2006; WONG; BABA, 2012). For example, in Malaysia, Wong and Baba (2012) have shown that patients with vitiligo with more exposed areas had higher DLQI scores than those with nonexposed areas. In China, a study verified the distribution pattern of vitiligo as a factor independently of QL using DLQI and SF-36 (WANG; WANG; ZHANG, 2011).In Germany, a study conducted in individuals with vitiligo showed that patients with spots on exposed areas had higher scores, and consequently lower QL, when compared to those with spots covered (RADTKE et al., 2009).Injuries to the face and / or exposed areas can lead to an increase in negative feelings, such as stress, anger, irritability and disillusionment, as well as mental disorders such as anxiety and depression, factors that negatively influence the QL of the patients (PARSAD et al. 2003; AMER, GAO, 2016).In general, some studies have shown a significant improvement of the QL after the use of camouflage for patients with vitiligo with exposed spots, suggesting the impact of the visibility of the lesions in the QL of these individuals (TANIOKA et al., 2010; ONGENAE et al., 2005). Similarly, in the present study, there was a positive association between the exposed involvement pattern of vitiligo and QL scores.

According to the scores, the main domains of DLQI influenced by vitiligo were daily activities, leisure, symptoms and feelings, followed by personal relationships. The domains work, school and treatment, presented very low scores, indicating that these ones promote little impairment of the QL of the individuals of the present study. In another study conducted in Italy, the main domains that influenced the QL of individuals with vitiligo were symptoms and feelings, followed by the domains personal relationships, leisure and daily activities. The domains related to work, school and treatment also presented lower scores (INGORDO et al., 2012).

Regarding the perceived stress, it was possible to identify that the patients with vitiligo present higher levels of perceived stress in the PSS10 when compared to the control group. A study conducted in patients with vitiligo and control group with dystrophic epidermolysis bullosa, cleft lip, melanocytic nevus or secondary disfigurement to trauma or burns, showed that patients with vitiligo presented significantly higher scores when compared to the control group (PAPADOPOULOS et al., 1998). Another study conducted in Romania in 32 patients with vitiligo and controls with nonstress-related skin diseases showed a significant difference in the average number of stressful events between patients and controls in the group of women (MANOLACHE; BENEA, 2007).

Several studies have shown that skin diseases, such as vitiligo, have their own characteristics that affect physical and psychological well-being (CHOI et al., 2010), including perceived stress. A number of factors contribute to increased perceived stress in people with vitiligo, such as prejudice and discrimination by society (PARSAD et al., 2003), social isolation, psychological distress (PAPADOPOULOS et al., 1998), lower perceived social support, low self-esteem (PICARDI et al., 2003) and higher prevalence of psychiatric comorbidities, such as depression and anxiety (MECHRI et al., 2006). In this sense, the high levels of perceived stress can be explained by these factors.

In the present study, there was a positive association between high perceived stress scores and QL. Vitiligo is in the group of dermatological diseases that affect the self-esteem of the patient, and can trigger isolation and depression. In addition, the chronic and non-aesthetic characters of vitiligo 
are associated with a greater degree of psychological distress that often requires psychological intervention (TABORDA et al., 2005). It is estimated that, in at least one third of patients, an effective treatment involves considerations about the associated emotional factors (GHAJARZADEH; GHIIASI; KHEIRKHAH, 2012). Stress is an adaptive response of the organism, considering individual and, or psychological characteristics, resulting in physical or psychological demands of each human being (BATISTA, 2011). Patients suffering from skin diseases suffer from emotional problems such as stress, anxiety and depression, compromising the QL (KIPRONO et al., 2013).

The present study has some limitations. First, the absence of a control group composed of individuals with other dermatoses (eg. psoriasis) limits the comparison of DLQI scores with other groups. Second, by the nature of the DLQI it was not possible to compare the QL scores with a control group composed of healthy individuals. Third, the transverse nature of factors associated with QL limits the establishment of cause and effect relationships. In addition, other determinants of QL, such as anxiety and depression were not investigated in this study. Despite the limitations, the study showed that factors associated with the QL of people with vitiligo, data that can subsidize actions to improve the QL of the carriers. From the obtained results, it is evidenced the importance of new studies conducted in Brazil that seek to evaluate the influence of the psychoemotional aspects present in the QL.

\section{CONCLUSION}

The average QL score using DLQI in patients with vitiligo was 4.7 points, indicating light impairment in QL. There was an association between QL and black skin color, pattern of exposed involvement of the disease and perceived stress in the investigated sample. Also, an association between vitiligo and perceived stress was observed using the PSS-10 instrument. The assessment of QL and perceived stress should be introduced as a key indicator in clinical practice and care of patients.

\section{ACKNOWLEDGEMENTS}

We appreciate the cooperation of the people working in the dermatology clinic of the Hospital where there was the recruitment of volunteers to carry out the research.

RESUMO: Avaliar a associação entre qualidade de vida, percepção de estresse em portadores de vitiligo e comparar a percepção de estresse com não portadores. Métodos: O primeiro estudo foi transversal, e o segundo caso-controle realizado com 51 pacientes em tratamento ambulatorial e 51 usuários de um hemocentro, pareados por sexo e idade. Utilizaram-se os questionários Dermatology Life Quality Index e a Escala de Estresse Percebido. Resultados: O escore médio de qualidade de vida nos portadores foi de 4,7 $\pm 5,8$, demonstrando um comprometimento leve na QV. Verificou-se associação entre QV e cor da pele negra ( $\mathrm{p}<$ $0,001)$, padrão de envolvimento do vitiligo exposto $(p<0,001)$ e estresse percebido $(p=0,033)$. O estresse

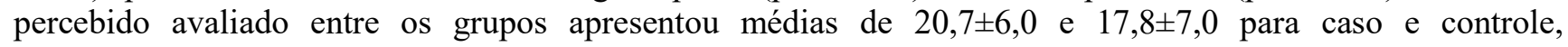
respectivamente. Portadores do vitiligo apresentaram percepção de estresse mais elevada quando comparado ao grupo controle $(\mathrm{p}=0,022)$. Os resultados apontaram uma percepção elevada de estresse nos portadores de vitiligo, sugerindo que a doença aumenta o nível de estresse. A pontuação geral da qualidade de vida foi relativamente baixa, indicando comprometimento leve da doença sobre a qualidade de vida.

PALAVRAS-CHAVE: Pele. Estresse Percebido. Qualidade de vida.

\section{REFERENCES}

AHMED, S.; HOQUE, M. E.; SARKER, A. R.; SULTANA, M.; ISLAM, Z.; GAZI, R.; et al. Willingness-toPay for Community-Based Health Insurance among Informal Workers in Urban Bangladesh. PLoS One, San Francisco, California, US, v. 11, n. 2, p. e0148211, 2016. https://doi.org/10.1371/journal.pone.0148211 
ALIKHAN, A.; FELSTEN, L. M.; DALY, M.; PETRONIC-ROSIC, V. Vitiligo: a comprehensive overview Part I. Introduction, epidemiology, quality of life, diagnosis, differential diagnosis, associations, histopathology, etiology, and work-up. J Am Acad Dermatol., Washington, D.C., United States v. 65, n. 3, p. 473-91, 2011. https://doi.org/10.1016/j.jaad.2010.11.061

AMER, A. A. A.; GAO, X-H.. Quality of life in patients with vitiligo: an analysis of the dermatology life quality index outcome over the past two decades. Int J Dermatol., Maryland, USA, v. 55, n. 6, p. 608-14, 2016. https://doi.org/10.1111/ijd.13198

BATISTA, K. M. Stress e Hardiness entre enfermeiros hospitalares. São Paulo: Universidade de São Paulo; Tese (Doutorado) - Escola de Enfermagem da Universidade de São Paulo, 2011, 239 p.

BOTH, H.; ESSINK-BOT, M. L.; BUSSCHBACH, J.; NIJSTEN, T.. Critical review of generic and dermatology-specific health-related quality of life instruments. J Invest Dermatol., USA, v. 127, n. 12, p. 2726-39, 2007. https://doi.org/10.1038/sj.jid.5701142

CHAN, M. F.; THNG, T. G.; AW, C. W.; GOH, B. K.; LEE, S. M.; CHUA, T. L.. Investigating factors associated with quality of life ofe vitiligo patients in Singapore. Int J Nurs Pract., Austrália, v. 19, Suppl 3, p. 3-10, 2013. https://doi.org/10.1111/ijn.12179

DOLATSHAHI, M.; GHAZI, P.; FEIZY, V.; HEMAMI, M. R.. Life quality assessment among patients with vitiligo: comparison of married and single patients in Iran. Indian J Dermatol Venereol Leprol, Kolkata/India, v. 74, n. 6, p. 700, 2008. https://doi.org/10.4103/0378-6323.45141

GHAJARZADEH, M.; GHIASI, M.; KHEIRKHAH, S. Associations between skin diseases and quality of life: a comparison of psoriasis, vitiligo, and alopecia areata. Acta Med Iran, Tehran, Iran.v. 50, n. 7, p. 511-5, 2012.

HONGBO, Y.; THOMAS, C. L.; HARRISON, M. A.; SALEK, M. S.; FINLAY, A. Y.. Translating the Science of quality of life into practice: What do drmatology life quality index scores means?. J Invest Dermatol., USA, v. 125, n. 4, p. 659-64, 2005. https://doi.org/10.1111/j.0022-202X.2005.23621.x

INGORDO, V.; CAZZANIGA, S.; GENTILE, C.; IANNAZZONE, S. S.; CUSANO, F.; NALDI, L. Dermatology Life Quality Index score in vitiligo patients: a pilot study among young Italian males. G Ital Dermatol Venereol., Itália, v. 147, n. 1, p. 83-90, 2012.

KIPRONO, S.; CHAULA, B.; MAKWAYA, C.; NAAFS, B.; MASENGA, J. Quality of life of patients with vitiligo attending the Regional Dermatology Training Center in Northern Tanzania. Int J Dermatol., Maryland, USA, v. 52, n. 2, p. 191-4, 2013. https://doi.org/10.1111/j.1365-4632.2012.05600.x

KOSTOPOULOU, P.; JOUARY, T.; QUINTARD, B.; EZZEDINE, K.; MARQUES, S.; BOUTCHNEI, S.; et al. Objective vs. subjective factors in the psychological impact of vitiligo: the experience from a French referral centre. Br J Dermatol., Reino Unido, v. 161, n. 1, p. 128-33, 2009. https://doi.org/10.1111/j.13652133.2009.09077.x

MANOLACHE, L.; BENEA, V. Stress in patients with alopecia areata and vitiligo. J Eur Acad Dermatol Venereol., Switzerland, v. 21, n. 7, p. 921-8, 2007. https://doi.org/10.1111/j.1468-3083.2006.02106.x

MARTINS, G. A.; ARRUDA, L.; MUGNAINI, A. S. B.. Validação de questionários de avaliação da qualidade de vida em pacientes de psoríase. An bras Dermatol., Rio de Janeiro, v. 79, n. 5, p. 521-35, 2004.

http://dx.doi.org/10.1590/S0365-05962004000500002 
MASHAYEKHI, V.; Z, Z. J.; KIAFAR, B.; MANTEGHI, A. A.; SAADATIAN, V.; ESMAEILI, H. A.; et al. Quality of life in patients with vitiligo: a descriptive study on 83 patients attending a PUVA therapy unit in Imam Reza Hospital, Mashad. Indian J Dermatol Venereol Leprol., Kolkata/India, v. 76, n. 5, p. $192,2010$. https://doi.org/10.4103/0378-6323.69097

MECHRI, A.; AMRI, M.; DOUARIKA, A. A.; HICHEM, B. H. A.; ZOUARI, B.; ZILI, J. Psychiatric morbidity and quality of life in Vitiligo: a case controlled study. Tunis Med., Tunisia, v. 84, n. 10, p. 632-5, 2006.

MERLI, A.; SERRA, E.; MONTENEGRO, V.; PASCUAL, L.. Impacto de calidad de vida en vitíligo. Arch Argent Dermatol., Rosário, Argentina, v. 64, n. 4, p. 139-43, 2014.

ONGENAE, K.; DIERCKXSENS, L.; BROCHEZ, L.; GEEL, NV.; NAEYAERT, J. M.. Quality of Life and Stigmatization Profile in a Cohort of Vitiligo Patients and Effect of the Use of Camouflage. Dermatology, Bethesda, USA, v. 210, n. 4, p. 279-85, 2005. https://doi.org/10.1159/000084751

ONGENAE, K.; GEEL, N. V.; SCHEPPER, S. D.; NAEYAERT, J. M.. Effect of vitiligo on self-reported health-related quality of life. Br J Dermatol., Reino Unido, v. 152, n. 6, p. 1165-72, 2005. https://doi.org/10.1111/j.1365-2133.2005.06456.x

PAPADOPOULOS, L.; BOR, R.; LEGG, C.; HAWK, J. L. Impact of life events on the onset of vitiligo in adults: preliminary evidence for a psychological dimension in aetiology. Clin Exp Dermatol., Norwich, Reino Unido, v. 23, n. 6, p. 243-8, 1998. https://doi.org/10.1046/j.1365-2230.1998.00384.x

PARSAD, D.; PANDHI, R.; DOGRA, S.; KANWAR, A. J.; KUMAR, B.. Dermatology Life Quality Index score in vitiligo and its impact on the treatment outcome. Br J Dermatol., Reino Unido, v. 148, n. 2, p. 373-4, 2003. https://doi.org/10.1046/j.1365-2133.2003.05097_9.x

PICARDI, A.; PASQUINI, P.; CATTARUZZA, M. S.; GAETANO, P.; MELCHI, C. F.; BALIVA, G.; et al. Stressful life events, social support, attachment security and alexithymia in vitiligo. A case-control study. Psychother Psychosom, Bologna v. 72. n. 3, p. 150-8, 2003. https://doi.org/10.1159/000069731

RADTKE, M. A.; SCHÄFER, I.; GAJUR, A.; LANGENBRUCH, A.; AUGUSTIN, M.. Willingness-to-pay and quality of life in patients with vitiligo. Br J Dermatol., Reino Unido, v. 161, n. 1, p. 134-9, 2009. https://doi.org/10.1111/j.1365-2133.2009.09091.x

RAZALI, N. M.; WAH, Y. B.. Power comparisons of Shapiro-Wilk, Kolmogorov-Smirnov, Lilliefors and Anderson-Darling tests. J Stat Model Analytics, Malasia, v. 2, n. 1, p. 21-33, 2011.

REIS, R. S.; HINO, A. A.; AÑEZ, C. R. Perceived stress scale: reliability and validity study in Brazil. J Health Psychol., Gainesville, USA, v. 15, n. 1, p. 107-14, 2010. https://doi.org/10.1177/1359105309346343

SHAH, M.; COATES, M. An assessment of the quality of life in older patients with skin disease. Br $\mathbf{J}$ Dermatol., Reino Unido, v. 154, n. 1, p. 150-3, 2006. https://doi.org/10.1111/j.1365-2133.2005.06959.x

SILVERBERG, J. I.; SILVERBERG, N. B. Association between vitiligo extent and distribution and quality-oflife impairment. JAMA Dermatol., Chicago, Illinois, EUA v. 149, n. 2, p. 159-64, 2013.

https://doi.org/10.1001/jamadermatol.2013.927

SILVERBERG, N. B.. The Epidemiology of Vitiligo. Current Dermatology Reports, Switzerland, v. 4, n. 1, p. 36-44, 2015. https://doi.org/10.1007/s13671-014-0098-6

TABORDA, M-L. V. V.; WEBER, M. B.; FREITAS, E. S.. Assessment of the prevalence of psychological distress in patients with psychocutaneous disorder dermatoses. An Bras Dermatol., Rio de Janeiro, v. 80, n. 4, p. 351-4, 2005. http://dx.doi.org/10.1590/S0365-05962005000400004 
TANIOKA, M.; YAMAMOTO, Y.; KATO, M.; MIYACHI, Y.. Camouflage for patients with vitiligo vulgaris improved their quality of life. J Cosmet Dermatol., Canadá, v. 9, n. 1, p. 72-5, 2010.

https://doi.org/10.1111/j.1473-2165.2010.00479.x

TAVAKOL, M.; DENNICK, R. Making sense of Cronbach's alpha. Int J Med Educ., Reino Unido, v. 2, p. 535, 2011. https://doi.org/10.5116/ijme.4dfb.8dfd

WANG, K. Y.; WANG, K. H.; ZHANG, Z. P.. Health-related quality of life and marital quality of vitiligo patients in China. J Eur Acad Dermatol Venereol., Switzerland, v. 25, n. 4, p. 439-35, 2011.

https://doi.org/10.1111/j.1468-3083.2010.03808.x

WHITE, H. A heteroskedasticity- consistent covariancematix estimator and a direct test for heteroskedasticity.

Econometrica, New York, USA, v. 48, n. 4, p. 817-38, 1980. https://doi.org/10.2307/1912934

WONG, S. M.; BABA, R.. Quality of life among Malaysian patients with vitiligo. Int J Dermatol., Maryland, USA, v. 51, n. 2, p. 158-61, 2012. https://doi.org/10.1111/j.1365-4632.2011.04932.x

ZHANG, Y.; CAI, Y.; SHI, M.; JIANG, S.; CUI, S.; WU, Y.; et al. The Prevalence of Vitiligo: A MetaAnalysis. PLoS One, San Francisco, California, US, v. 11, n. 9, p. e0163806, 2016.

https://doi.org/10.1371/journal.pone.0163806 